\title{
Reproductive health and birth practices among early married females: A cross-sectional study in Jaipur India
}

\author{
Chintu Chaudhary', Mohd. Najmul Aqib Khan², Sameena Ahmad ${ }^{3}$ \\ ${ }^{1}$ Asscociate Professor, Department of Community Medicine, Al-Falah School of Medical Sciences and Research \\ Centre, Faridabad, Haryana, ${ }^{2}$ Assisstant Professor, Department of Community Medicine, Government Medical College, \\ Haldwani, Uttarakhand, ${ }^{3}$ Senior Resident, Department of Community Medicine, Jawaharlal Nehru Medical College, \\ Aligarh Muslim University, Aligarh, Uttar Pradesh, India
}

Background: Early marriage is not only a violation of females but also causes harm to their physical and psychological health. Aims and Objectives: The aim of the study was to determine the prevalence of early marriage and its association with reproductive health of females. Materials and Methods: This community based cross-sectional study was conducted among 322 married females in the field practice areas of JNU-IMRC, Jaipur, Rajasthan. The data were analyzed using Statistical Package for the Social Sciences 20.0. Results: The study found that $53.4 \%$ of the females had married before the age of 18 years. Significant associations were found between age at marriage, their socio-economic status, number of children, awareness of contraception, and history of various obstetric complications $(\mathrm{P}<0.05)$. Conclusion: The study brings forth the fact that early marriages have an adverse effect on reproductive health of the females. Rigorous efforts and policies should be put in place for the adolescents to understand their reproductive health better.

Key words: Birth practices; Early marriage; Reproductive health; Rural
Access this article online Website: http://nepjol.info/index.php/AJMS DOI: 10.3126/ajms.v13i1.40269 E-ISSN: 2091-0576 P-ISSN: 2467-9100

Copyright (c) 2022 Asian Journal of Medical Sciences

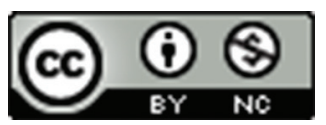

This work is licensed under a Creative Commons Attribution-NonCommercial 4.0 International License.

\section{INTRODUCTION}

Marriage is considered as a time of celebration and marks the transition to adulthood all over the world. ${ }^{1}$ It is known as a very important event in adult life in many countries where it is regarded as the only socially acceptable way to procreate. In essence, marriage defines the beginning of a socially acceptable sexual and child bearing period. It can be said without a doubt that adolescence is a critical period in the life of a girl child as it is this period that is considered to shape the future of adolescent females. ${ }^{2}$ Child marriage refers to any formal marriage or informal union between a child under the age of 18 years and an adult or another child. ${ }^{3}$ It is practiced in the country as a result of deep seated gender inequality, which disproportionately affected girls. ${ }^{3}$ Early marriages have been reported to result in higher school dropout rates, low wages and high unemployment rates, not to mention the poor health status and higher crime rates against women. ${ }^{4}$ Child marriage is now firmly on the global development agenda, most prominently through its inclusion in Sustainable Development Goal target 5.3, which aims to eliminate the practice by 2030, and indicator 5.3.1 which measures proportion of women aged 20-24 years who were married or in a union before age of 15 and 18 years. ${ }^{5}$ The principal causes leading to this stigmatized custom against adolescent girls can be considered as poverty, protection of the adolescent girls and reinforcement of social ties. ${ }^{6}$ Along with this, girls 
from rural background are also reported to be at a higher risk of this practice. ${ }^{7}$ Young mothers are also said be at a higher risk of sexually transmitted diseases, cervical cancer, malaria, death during childbirth, and obstetric fistulas, to name a few. ${ }^{8}$ Not only this, girls marrying early also suffer from a gamut of complications during their delivery thereby putting their health at risk. ${ }^{9}$ The prime reason for parents marrying their girl child early could be to protect their righteousness and health including prevention of sexually transmitted infections, such as acquired immune deficiency syndrome. ${ }^{10}$ Child brides become mothers at an early age, often because they are under intense social pressure to prove their fertility. They are more likely to experience early, frequent, and often unwanted pregnancies. Where girls survive childbirth, they are at increased risk of post pregnancy-related complications. For example, $65 \%$ of all cases of obstetric fistula occur in girls under the age of $18 .{ }^{11}$ Not only they are susceptible to complications after delivery, they are also vulnerable to stillbirth, miscarriage, and wasted pregnancies, to name a few. ${ }^{12}$ Lack of contraceptive practices among child brides is also one of the factors behind these antenatal and postnatal complications. Limited researches are available on how early marriage may limit young women's lives and compromise their choices. Particularly, not much has been documented regarding the association between age at marriage and their reproductive health. In India, gender equality is far from achieved due to various challenges in the society, which majorly include violence against women and gender discrimination. ${ }^{13}$ Keeping the above discussed social problems in mind the present study was conducted.

\section{Aims and objectives}

The aim of the study was to determine the prevalence of early marriage in the study area, its socio demographic determinants, and its association with reproductive health of the females.

\section{MATERIALS AND METHODS}

It was a community-based cross-sectional study conducted in field practice areas of JNU-IMSRC, Jaipur, Rajasthan, during first half of 2019 after taking ethical clearance from the concerned committee (JNUIMSRC/IEC/2019/60). Literature review revealed that the prevalence of child marriage in India is $27 \% .{ }^{14}$ Assuming this prevalence with relative error of $5 \% \mathrm{t}$ at level of significance of $95 \%$, the sample size was calculated.

The equation used for calculating sample size is as follows:

$$
\mathrm{n}=\frac{\mathrm{Z}^{2} \mathrm{P}(1-\mathrm{P})}{\mathrm{e}^{2}}
$$

Where,

$\mathrm{Z}=$ Level of confidence $-95 \%$ (1.96)

$\mathrm{P}=$ Prevalence of early marriage

$\mathrm{e}=$ Margin of error

The sample size came out to be approximately 303 . Assuming non-response rate to be 5\%,322 married females were taken up for the study.

Data collected was analyzed using Statistical Package for the Social Sciences 20.0 software. Proportions and percentages were computed for categorical data. Statistical significance was considered at $\mathrm{P}<0.05$.

A house-to-house survey was conducted in the rural field practice area of JNU-IMSRC. A village from the study area was selected randomly by lottery method. First house in the village was selected randomly to start data collection and every alternate house was taken for survey till target sample size is achieved. A semi-coded and pretested questionnaire in local language (Hindi) was used to collect the relevant information.

Informed consent was taken from all the participants. The data were collected over a period of 2 months.

\section{Inclusion criteria}

Women having a married life of $<10$ years were included in the study to minimize recall bias. The age at marriage was confirmed either orally or from marriage certificate if available. Events related to pregnancy and child birth were confirmed from the available records such as antenatal card. When these records were not available, this information was sought from the respondent.

\section{Exclusion criteria}

Those with married life more than 10 years and those not gave consent to participate in the study.

\section{RESULTS}

According to the study, it was found that more than half $(\mathrm{n}=172,53.4 \%)$ of the study participants reported to have been married before the legal age of 18 years (Table 1).

The mean age of the included women, at the time of interview for the study, was found to be $27.39 \pm 5.56$ years for early married subjects $(n=172)$, and $28.76 \pm 5.07$ years $(n=150)$ for those married after 18 years. The mean age of the spouse in the two groups was found to be $31.45 \pm 6.18$ and $31.95 \pm 5.92$ years, respectively. However, the mean marital age of $15.84 \pm 1.92$ years was reported among early married females while it came out to be $21.32 \pm 2.49$ years 


\begin{tabular}{|c|c|c|c|}
\hline $\begin{array}{l}\text { S. } \\
\text { No. }\end{array}$ & Age at marriage of women & Frequency & Percent \\
\hline 1. & $<18$ years & 172 & 53.4 \\
\hline 2. & $>18$ years & 150 & 46.6 \\
\hline 3. & Total & 322 & 100.0 \\
\hline
\end{tabular}

among females who got married after 18 years. Similarly, the mean marital age of male partners of early married females was found to be $19.97 \pm 3.49$ years which itself, is less than the legal marital age for boys in the country and stands at 21 years. On the other hand, males who had married females of age 18 years and more had mean marital age as $24.10 \pm 3.52$ years. The mean age of women at the delivery of the first child was found to be $17.80 \pm 4.65$ years in case of females marrying early while it was $21.40 \pm 6.51$ years among women marrying later. Furthermore, the time interval between marriage and delivery of the first child was observed much less (1.37 \pm 3.57 years) among females getting married at $<18$ years while the same was noted to be a bit more $(2.86 \pm 2.79$ years) in case of females marrying later. The difference between means for the last two variables was significant.(Table 2).

As for the socio-demographic determinants, statistically non-significant association was found between marital age and religion where a large number of females $(74.4 \%)$ married under 18 years of age belonged to Hinduism while rest were Muslims. Similarly, in case of females married after 18 years of age, $80 \%$ were followers of Hindu religion while the rest were Muslims. Statistically significant associations $(\mathrm{P}<0.05)$ were found between marital age and educational status, socio-economic status, nature of employment, education status of the male partner, and number of children in the family. It was observed that practices of marriage before 18 years of age was more prevalent among females who were illiterate $(n=61$, $35.5 \%)$, belonged to middle socio economic status $(n=102$, $59.3 \%)$, and had 3 or more children ( $\mathrm{n}=139,80.8 \%)$. Also, males who were laborers $(n=81,47.1 \%)$, illiterate $(n=48$, $27.1 \%)$ or had maximum education up to high school $(\mathrm{n}=90,52.3 \%)$, found to have married an underage girl predominantly. Statistically non-significant association of early marital age was observed with employment status and marital status of the females ( $p>0.05)$ (Table 3).

Regarding reproductive health of the females, it was noted that a little less than half $(n=70,40.7 \%)$ of the study participants among younger age group ( $<18$ years) had a history of vaginal discharge while $49.3 \%(\mathrm{n}=74)$ females marrying later had the same complaint. No history of the lower abdominal pain was elicited among majority of the females who had married early $(\mathrm{n}=90,52.3 \%)$, while the same was found to be prevalent among females marrying later than 18 years $(\mathrm{n}=82,54.7 \%)$. The same pattern was observed in case of unwanted pregnancies where $82.6 \%$ $(\mathrm{n}=142)$ had borne children before the age of 18 years, while $86.7 \%(n=130)$ were able to delay their pregnancies. All three of these associations were not found to be statistically significant $(\mathrm{P}>0.05)$ (Table 4).

Awareness about contraception was found to be rampant among women marrying later at $62.7 \%(\mathrm{n}=94)$ as compared to females getting married early ( $42.7 \%$, $\mathrm{n}=82$ ). This association was found to be statistically significant $(\mathrm{P}<0.01)$. In case of contraception usage, it was recorded that women marrying at $<18$ years of age had more temperament to use contraception after marriage $(69.8 \%, n=120)$, the prevalence of which increased after birth of the first child $(83.7 \%, \mathrm{n}=144)$ as compared to women marrying late $(67.3 \%, \mathrm{n}=101 ; 76.0 \%, \mathrm{n}=114$, respectively). Both of these associations were not found to be statistically significant. History of abortion was found in majority among females who had married late $(76.0 \%$, $\mathrm{n}=114)$. This association was not found to be statistically significant $(\mathrm{P}>0.05)$. However, significant association was found between early marriage and prolonged labor in case of early married females ( $\mathrm{n}=143,83.1 \%)(\mathrm{P}<0.05)$. Obstructed labor was observed to be a prominent problem in early marriages $(96.5 \%, \mathrm{n}=166)$, but the association between these variables was not found to be significant $(\mathrm{P}>0.05)$. As expected, the prevalence of vesico-vaginal fistula was observed to be higher among females marrying early $(77.3 \%, \mathrm{n}=133)$ as compared to females marrying later than 18 years $(66.7 \%, \mathrm{n}=100)$. This association was found to be statistically significant $(\mathrm{P}<0.05)$. History of medical termination of pregnancy (MTP) was ubiquitous among females marrying late $(94.7 \%, \mathrm{n}=142)$ as compared to early married females $(87.8 \%, \mathrm{n}=151)$. This association was found to be statistically significant $(\mathrm{P}<0.05)$. History of stillbirth $(84.0 \%, \mathrm{n}=126)$ and delivery of last child at a health facility/hospital $(77.3 \%, \mathrm{n}=116)$ was found to be positive majorly among females marrying late, the association of which was not found to be significant $(\mathrm{P}>0.05)$. Furthermore, statistically significant association $(\mathrm{P}<0.05)$ was found between early marriage of females and number of children having birth order of three or more $(80.8 \%, \mathrm{n}=139)$.

\section{DISCUSSION}

Despite laws against it, the practice of early marriage remains widespread around the globe especially in developing countries. Worldwide, one in every five girls is married, or in union, before reaching age 18. In the least developed countries, that number even doubles - 
$40 \%$ of girls are married before the age of 18 , and $12 \%$ before the age of 15 years. ${ }^{5}$ In India, $40 \%$ of the females are reported to be married before reaching the legal age. ${ }^{14}$ In our study, the prevalence of early marriage was found to be $53.4 \%$ in the study population, much higher than the state's prevalence of $35.4 \%$ in Rajasthan itself, $36.22 \%{ }^{15}$ in Manipur, and $42.5 \%$ in Bihar-all reported early marriage above the national average. ${ }^{14}$ According to National Family Health Survey 4 data, the median age at marriage for females in the country has been observed to be 19.0 years, while for men it is 24.5 years; both of which have seen a rise from 17.2 years to 22.6 years, respectively..$^{14}$ In the present study, however, the mean age at marriage of women marrying before the legal age was found to be $15.84 \pm 1.92$ years, while for men it was $19.97 \pm 3.49$ years. A study, conducted in Sudan, reported concordant findings with the present study with mean age of marriage at 15.4 years. ${ }^{16}$ The practice of early marriage was found to be more prevalent among Hindus (74.4\%) which was in concordance with another study which also reported higher prevalence of the same among Hindus, probably because of social, economic, and health perspectives. ${ }^{17}$ Islam has also been reported to be a higher contributor to child brides in a study in Nigeria where religion plays a significant role in shaping values and practices at individual, household and community level, including girl-child development issues. ${ }^{16}$

As this study was conducted in a rural population, the higher prevalence of early marriage $(53.4 \%)$ was found to be similar to the findings in studies conducted in countries such as Nigeria and Bangladesh. ${ }^{16,18}$ Patriarchy, coercion, social customs, and norms could be mentioned as principal determinants in case of forcing girls into marrying early. ${ }^{19}$ Education, almost universally, plays a protective effect in delaying early marriage, among both girls and boys. In a patriarchal society like India where inequality is deeply rooted in its socio-cultural norms, girls have little opportunities for their education. Most of them drop-out before the completion of secondary education because of early age at marriage. ${ }^{12}$ Similar to this study, an inverse association between education status and early marriage, also surfaced previously by other researchers. ${ }^{16,20}$ Early marriage and socio economic status, also found to have a significant association, wherein females, belonging to lower socio-economic status were more among early married ones. The same has been depicted in studies conducted in various countries worldwide, ${ }^{21,22}$ as well as in the country itself. ${ }^{12}$ Furthermore, in our study, the results have been found to be consistent with other studies primarily because poor families often tend to think that marrying their girl child early, will provide social and financial security to their daughters. ${ }^{23}$ Cultural family structure, weak authority of females, and responsibility to fulfill needs, also forces parents of a girl child to marry their child at a younger age..$^{24}$

In our study, it was observed that husbands who were involved in labor as well as those having education till high school were more likely to marry females less than the national legal age for marriage. Lack of proper education and societal pressures may be the reasons for this. As a result of getting into illegal and immature union, boys discontinue their education and do not find motivation to finish their studies due to added pressure to support the family. ${ }^{25}$ The responsibility of financial management in our study was found to primarily rest with the male counterpart only, probably because in Indian society, males are supposed to be playing the role of head of the family. ${ }^{26}$ As far as fertility is concerned, significant associations were found between high fertility (three or more children) and early marriage, similar to a study done in Africa ${ }^{20}$ which demonstrated high odds' ratio (OR=8.00; $95 \%$ CI: 7.52, 8.46) of more number of children when females were married early. This could be because of lack of knowledge or access to contraceptive services, or increased control by in-laws which is a very prominent feature of Indian society. ${ }^{27}$

We found that, presence of vaginal discharge and age of marriage were not significantly associated, wherein positive history of the same was elicited more, in females married after 18 years, compared to early married ones. Similar findings of elderly females having higher prevalence of vaginal discharge as compared to females $<18$ years of age was reported in another study done in India; ${ }^{28}$ however, they reported a significant association, contrary to the findings of present study. In contrast, another study reported that early marriage comes with risk of having profuse vaginal discharge, as early onset of sexual activity may make the cervical epithelium more susceptible to ascending infections. ${ }^{29}$ Furthermore, not opting any contraceptive method, early child bearing and obstetric morbidity also contribute towards the problem. ${ }^{29}$ History of the lower abdominal pain was also found to be more prevalent in females married late with a non-significant association with early marriage in this study. Similar findings reported by other researchers in New Delhi, India, ${ }^{30}$ wherein early married females had less odds of suffering from lower abdominal pain, but with a statistically significant association. Regarding unwanted pregnancies, the prevalence of the same was more for females married late but the association between age at marriage and unwanted pregnancies was not found to be statistically significant. A study conducted in Sub-Saharan Africa also revealed that older women had a higher prevalence of unwanted pregnancies as compared to females marrying early. ${ }^{20}$ However, this was discordant with an Indian study which reported more number of unwanted pregnancies 
with child marriage as early marriage reduces the women's control over reproduction in social context, be it either due to lack of contraceptive practices or due lack of accessibility for the same. ${ }^{27}$
In our study, significant association between awareness of contraception and early marriage was observed, as more number of early married females were aware about contraception, compared to females in other group.

Table 2: Mean age of women and their spouses, when interviewed and at marriage; and women's age at first delivery

\begin{tabular}{|c|c|c|c|c|}
\hline Variable & Marital age group & $\mathbf{N}$ & Mean & SD \\
\hline \multirow[t]{2}{*}{ Age of women } & Less than18 years & 172 & 27.39 & 5.56 \\
\hline & More than 18 years & 150 & 28.76 & 5.07 \\
\hline \multirow[t]{2}{*}{ Age of husband } & Less than18 years & 172 & 31.45 & 6.18 \\
\hline & More than 18 years & 150 & 31.95 & 5.92 \\
\hline \multirow[t]{2}{*}{ Age of women at marriage } & Less than 18 years & 172 & 15.84 & 1.92 \\
\hline & More than 18 years & 148 & 21.32 & 2.49 \\
\hline \multirow[t]{2}{*}{ Age of husband at marriage } & Less than 18 years & 172 & 19.97 & 3.49 \\
\hline & More than 18 years & 150 & 24.10 & 3.52 \\
\hline \multirow[t]{2}{*}{ Women's age at first child delivery* } & Less than 18 years & 166 & 17.80 & 4.65 \\
\hline & More than 18 years & 140 & 21.40 & 6.51 \\
\hline \multirow[t]{2}{*}{ Time interval between marriage and first child* } & More than 18 years & 162 & 2.86 & 2.79 \\
\hline & Less than 18 years & 130 & 1.37 & 3.57 \\
\hline
\end{tabular}

$* P<0.001$

Table 3: Socio-demographic determinants of study population

\begin{tabular}{|c|c|c|c|}
\hline Parameter & $\begin{array}{c}\text { Marital age }<18 \text { years } \\
\mathrm{N}(\%)\end{array}$ & $\begin{array}{c}\text { Marital age }>18 \text { years) } \\
\mathrm{N}(\%)\end{array}$ & P-value \\
\hline \multicolumn{4}{|l|}{ Religion } \\
\hline Hindu & $128(74.4)$ & $120(80.0)$ & \\
\hline Muslim & $44(25.6)$ & $30(30.0)$ & 0.38 \\
\hline \multicolumn{4}{|l|}{ Educational status } \\
\hline Illiterate & $61(35.5)$ & $25(16.7)$ & $<0.001^{*}$ \\
\hline Primary & 33 (19.2) & $14(9.3)$ & \\
\hline High School & $58(33.7)$ & $53(35.3)$ & \\
\hline Senior Secondary & $11(6.4)$ & $14(9.3)$ & \\
\hline Graduate & $8(4.7)$ & $25(16.7)$ & \\
\hline Post Graduate & $1(0.6)$ & $19(12.7)$ & \\
\hline \multicolumn{4}{|l|}{ Employment status } \\
\hline Employed & $128(74.4)$ & $120(80)$ & 0.28 \\
\hline Home maker & $44(25.6)$ & $30(30)$ & \\
\hline \multicolumn{4}{|l|}{ Socioeconomic status } \\
\hline Low & $70(40.7)$ & $28(18.7)$ & $<0.001^{*}$ \\
\hline Middle & $102(59.3)$ & $122(81.3)$ & \\
\hline \multicolumn{4}{|l|}{ Marital status } \\
\hline Divorced/Separated & $2(1.2)$ & $2(1.3)$ & 0.99 \\
\hline Currently Married & $170(98.8)$ & 148 (98.7) & \\
\hline \multicolumn{4}{|l|}{ Husband's employment } \\
\hline Private Job & 49 (28.5) & $81(54.0)$ & $<0.001^{*}$ \\
\hline Driver & $31(18.0)$ & $14(9.3)$ & \\
\hline Government Job & $2(1.2)$ & $12(8.0)$ & \\
\hline Self Employed & $1(0.6)$ & $2(1.3)$ & \\
\hline Laborer & $81(47.1)$ & $29(19.3)$ & \\
\hline Others & $8(4.7)$ & $12(8.0)$ & \\
\hline \multicolumn{4}{|l|}{3 or more children } \\
\hline Yes & $139(80.8)$ & $90(60.0)$ & $<0.001^{*}$ \\
\hline No & $33(19.2)$ & $60(40.0)$ & \\
\hline \multicolumn{4}{|l|}{ Husband's education } \\
\hline Illiterate & $48(27.9)$ & $14(9.3)$ & $<0.001^{*}$ \\
\hline Primary & $16(9.3)$ & $12(8.0)$ & \\
\hline High School & $74(43.0)$ & $40(26.7)$ & \\
\hline Senior Secondary & $11(6.4)$ & 19 (12.7) & \\
\hline Graduate & $18(10.5)$ & $49(32.7)$ & \\
\hline Postgraduate & $5(2.9)$ & $16(10.7)$ & \\
\hline Total & $172(100)$ & $150(100)$ & \\
\hline
\end{tabular}


Table 4: Reproductive health and birth practices with age at marriage

\begin{tabular}{|c|c|c|c|}
\hline & Age of the fe & he of marriage & P-value \\
\hline & $\begin{array}{l}\text { Less than } 18 \text { years } \\
\mathrm{N}(\%)\end{array}$ & $\begin{array}{l}\text { More than } 18 \text { years } \\
\mathrm{N}(\%)\end{array}$ & \\
\hline History & & & \\
\hline Yes & $70(40.7)$ & 74 (49.3) & 0.12 \\
\hline No & $102(59.3)$ & 76 (50.7) & \\
\hline History & & & \\
\hline Yes & $82(47.7)$ & $82(54.7)$ & 0.22 \\
\hline No & $90(52.3)$ & $68(45.3)$ & \\
\hline Unwant & & & \\
\hline Yes & 142 (82.6) & $130(86.7)$ & 0.31 \\
\hline No & $30(17.4)$ & 20 (13.3) & \\
\hline Awaren & & & \\
\hline Yes & $90(52.3)$ & $56(37.3)$ & $<0.001^{* *}$ \\
\hline No & $82(42.7)$ & 94 (62.7) & \\
\hline Contrac & & & \\
\hline Yes & $120(69.8)$ & $101(67.3)$ & 0.08 \\
\hline No & $52(30.2)$ & 49 (32.7) & \\
\hline Contrac & & & \\
\hline Yes & $144(83.7)$ & $114(76.0)$ & 0.09 \\
\hline No & $28(16.3)$ & $36(24.0)$ & \\
\hline History & & & \\
\hline Yes & $129(75.0)$ & $114(76.0)$ & 0.89 \\
\hline No & $43(25.0)$ & $36(24.0)$ & \\
\hline History & & & \\
\hline Yes & $143(83.1)$ & $108(72)$ & $0.02^{* *}$ \\
\hline No & $29(16.9)$ & $42(28)$ & \\
\hline History & & & \\
\hline Yes & $166(96.5)$ & $141(94)$ & 0.30 \\
\hline No & $6(3.5)$ & $9(6)$ & \\
\hline History & & & \\
\hline Yes & $133(77.3)$ & $100(66.7)$ & $0.03^{* *}$ \\
\hline No & $39(22.7)$ & $50(33.3)$ & \\
\hline History & & & \\
\hline Yes & $151(87.8)$ & $142(94.7)$ & $0.03^{\star *}$ \\
\hline No & $21(12.2)$ & $8(5.3)$ & \\
\hline History & & & \\
\hline Yes & $142(82.6)$ & $126(84.0)$ & 0.77 \\
\hline No & $30(17.4)$ & $24(16.0)$ & \\
\hline Hospita & & & \\
\hline Yes & $54(31.4)$ & $34(22.7)$ & 0.80 \\
\hline No & 118 (68.6) & 116 (77.3) & \\
\hline Birth orc & & & \\
\hline Yes & $139(80.8)$ & $90(60.0)$ & $<0.001^{* *}$ \\
\hline No & $33(19.2)$ & $60(40.0)$ & \\
\hline Total & $172(100)$ & $150(100)$ & \\
\hline
\end{tabular}

*Medial termination of pregnancy. ${ }^{* * P}<0.05$

Although insignificantly higher, contraceptive usage was also found to be more among females, married early. Study conducted in Bangladesh, also showed, that majority of the adolescents were aware of contraceptive options, but were not using any, due to socio-cultural environment and inadequate advise by the elder family members, because of their unfamiliarity with contraceptives. It is the usual belief that if the couple starts contraceptive use earlier, subsequently, the woman becomes infertile. Hence, in most of the cases, decision to use contraception comes either from husband or from the elders of the family. However, the trend is gradually changing as both husband and wife now take part in decision-making process about contraceptive use. Along with this, female education also plays a role in awareness of contraception and usage of the same along with delaying of marriage, thereby postponing the child bearing role of the woman. ${ }^{31}$ Furthermore, increased contraceptive use after marriage in early married females could also be attributed to the fact that they are able to bear the desired number of children at an early age, as discernible by high fertility among these women. ${ }^{20}$ Lack of contraceptive usage is also among major problems resulting in higher fertility among early married females as compared to females marrying late. The same was observed in another Indian study, wherein almost the same number of females $(80.0 \%)$ as in our study, had unmet need for 
contraception. The reasons for the same could vary from lack of knowledge about contraceptive methods, to poor accessibility to health services, to opposition of partner or family members. Apart from this, many females were observed to follow a fatalist attitude of considering children to be God's gift along, and hesitate to talk about contraception or negligent it. ${ }^{32}$

In this study, regarding health outcomes, females marrying late had marginal higher frequency of miscarriages, compared to early married females with a non-significant variance. Contrary, a study did report higher likelihood of miscarriage or wasted pregnancy (OR 1.15, $\mathrm{P}<0.01)$ among the women who married at age of $\leq 14$ years than those women who married at age of $\geq 18$ years. ${ }^{12}$ However, same study also documents, women who married at the age of 15-17 years were no longer significantly associated with pregnancy-related health outcomes, like in our study, where mean age at marriage is close to 16 years. Contributing factors leading to a high abortion rate in young females could be physical and psychological immaturity, controlling attitude of the elders toward reproductive health of the females, low education about sexual and reproductive health, pre mature birth and nutritional deficiencies etc. ${ }^{20,27}$ Appreciably, more number of early married study participants had history of prolonged labor and vesicovaginal fistulas, compared to females in other group. This is in line with other studies which reported health consequences of child bearing in early age, as young bodies of female adolescents are not developed strong enough to bear the force of childbearing. ${ }^{8,9,12,27}$ History of MTP in our study was found to be substantially higher in females married after 18 years. Other researchers also reported similar finding wherein more women, married after the legal age came to seek MTP, compared to younger females. ${ }^{33,34}$ This could be due to the fact that late marrying females might have completed their family and had suffered unwanted pregnancy due to which they sought MTP. In contrast, other studies have demonstrated the prevalence of pregnancy termination to be higher in early married females as compared to females married late. ${ }^{20,27}$ Still births among early married females also pose a major health hazard as these women often have poor socio-economic status, lower level of education, poor nutritional status, limited exposure to mass media, and live in backward areas, all of which have a negative impact on their pregnancy outcome. ${ }^{12}$ In case of hospital delivery of the last child among our study participants, it was observed that females married early had more institutional deliveries, compared to other group. In contrast, other studies conducted in India, and other countries as well, reported that, as the age progressed, females are more likely to opt for institutional deliveries. ${ }^{35-37}$ Along with this, in our study, it was also observed that majority of females married early, reported to be having a child of birth order to be three or more. This could be because of the fact that married adolescent females are exposed to sexual activity at a very early stage, and one of many reasons for it might be, that girls are supposed to prove their fertility in a country like India, as soon as get marry. Along with this, family's or husband's desire for a male heir or for more children, socio-economic and cultural factors, could also be some of the contributing factors toward higher fertility of early married females. ${ }^{20,38}$

\section{Limitations of the study}

The sample size of our study was not very large (322). Hence, we cannot not generalise the findings of this study to other parts of the country. Also, this study was cross sectional in nature, so a causal association between variables cannot be established. Further research can be done with a larger sample size in other parts of the country, especially with rural background to have a better and clear picture to support our study results.

\section{CONCLUSION}

From the present study, it can be concluded that early marriage is still persisting as an abomination in the society, against which, proper and drastic measures should be taken. Not only as much to safeguard the health of the females involved in early marriage per se, but also to maintain their reproductive health which takes a backseat in the vicious cycle of lack of education, knowledge, access to healthcare services, poor nutritional status, socio-economic, and cultural factors. Although India has made a huge progress in this field to curb this harmful practice, stringent measures and policies are still required to re-enforce the idea that early marriages should not be practiced. Passing a strict law against child marriage could be one step to curb this menace. Apart from this, adolescent girls should also be made aware of their rights, and proper policies and programs should be made available for their upliftment.

\section{ACKNOWLEDGMENT}

We are extremely thankful, to all the women who took part in the study, for their considerate cooperation.

\section{REFERENCES}

1. Waghmare R, BansodeGokhe S and Rasal M. A cross-sectional study of sociodemographic determinants of child marriage in an urban slum of Mumbai city: The challenge persists. Int J Med Sci Public Health. 2018;7(6):1. http://doi.org/10.5455/ijmsph.2018.0308220032018

2. Mpilambo JE, Susumanappunni S, Kanayo O and Stiegler N. Determinants of early marriage among young women in Democratic Republic of Congo. J Soc Sci. 2017;52(1-3):82-91. 
http://doi.org/10.1080/09718923.2017.1322393

3. UNICEF India. Child Marriage UNICEF. 2017;2006:1-3. https:// www.unicef.org/protection/child-marriage [Last accessed on 2021 Jun 23].

4. Dahl GB. Early teen marriage and future poverty. Demography. 2010;47(3):689-718.

http://doi.org/10.1353/dem.0.0120

5. UNICEF. Ending Child Marriage: A Profile of Progress in India UNICEF DATA. Published Online; 2019. p. 1-28. Available from: https://data.unicef.org/resources/ending-child-marriage-aprofile-of-progress-in-india. [Last accessed on 2021 Jun 21].

6. Mahato SK. Causes and consequences of child marriage: A perspective. Int J Sci Eng Res. 2016;7(7):698-702. Available from: http://www.ijser.org [Last accessed on 2021 Jun 23].

7. Child Marriage around the World UNICEF. UNICEF; 2020. Available from: https://www.unicef.org/stories/child-marriagearound-world [Last accessed on 2021 Jun 23].

8. Nour NM. Health consequences of child marriage in Africa. Emerg Infect Dis. 2006;12(11):1644-1649.

http://doi.org/10.3201/eid1211.060510

9. Adedokun $\mathrm{O}$, Adeyemi $\mathrm{O}$ and Dauda C. Child marriage and maternal health risks among young mothers in Gombi, Adamawa state, Nigeria: Implications for mortality, entitlements and freedoms. Afr Health Sci. 2016;16(4):986-999.

http://doi.org/10.4314/ahs.v16i4.15

10. Early Marriage: A Traditional Harmful Practice a Statistical Exploration UNICEF DATA; 2005. Available from: https:/l data.unicef.org/resources/early-marriage-a-traditionalharmful-practice-a-statistical-exploration [Last accessed on 2021 Jun 23].

11. Child Marriage and Family Planning: An Information Sheet; 2016. Available from: http://www.GirlsNotBrides.org [Last accessed on 2021 Jun 23]

12. Paul P. The Impact of Early Marriage on Pregnancy Outcomes of Ever-married Women: Findings from India Human Development Survey, 2011-12. Published Online; 2018. http://doi.org/10.4172/2167-0420.1000450

13. Sama AA. Women empowerment: Issues and challenges. Int $\mathrm{J}$ Indian Psychol. 2017;4(3):103.

http://doi.org/10.25215/0403.239

14. National Family Health Survey (NFHS-4) 2015-16: India. Mumbai: IIPS. National Family Health Survey (Nfhs-4) 201516. Int Inst Popul Sci ICF 2017. Published Online National Family Health Survey; 2017. p. 1-671. Available from: https:// dhsprogram.com/pubs/pdf/FR339/FR339.pdf. [Last accessed on 2021 Jun 21].

15. Singh K., Indira R and Minita N. Prevalence of early marriage among women in a muslim-dominated area of Manipur and its associated factors. Int J Res Health Sci. 2014;(4):1180-1184.

16. Ali AA, Ibrahim IA, Abdelgbar SA and Elgessim ME. Sociodemographic factors affecting child marriage in Sudan. J Womens Health Care. 2014;3(4):163. http://doi.org/10.4172/2167-0420.1000163

17. And the I was a Bride: Ana Analysis of Incidence of Child Brides across India a District Level Study Munich Personal RePEc Archive. Available from: https://mpra.ub.uni-muenchen. de/75317 [Last accessed on 2021 Jun 23].

18. Haq M. Relationship between age at marriage, education and fertility among residence of Bangladesh. Am J Soc Sci Res. 2018;4(2):33-39. Available from: http://www.aiscience.org/ journal/ajssr http://creativecommons.org/licenses/by/4.0. [Last accessed on 2021 Jun 21].

19. Seth R, Bose V, Qaiyum Y, Chandrashekhar R, Kansal S, Taneja
I and Seth T. Social determinants of child marriage in Rural india. Ochsner J. 2018;18(4):390-394.

http://doi.org/10.31486/toj.18.0104

20. Yaya S, Odusina EK and Bishwajit G. Prevalence of child marriage and its impact on fertility outcomes in 34 sub-Saharan African countries. BMC Int Health Hum Rights. 2019;19(1):33. http://doi.org/10.1186/s12914-019-0219-1

21. Efevbera $Y$, Bhabha J, Farmer $P$ and Fink $G$. Girl child marriage, socioeconomic status, and undernutrition: Evidence from 35 countries in Sub-Saharan Africa. BMC Med. 2019;17(1):55. http://doi.org/10.1186/s12916-019-1279-8

22. Der Vang $P$ and Bogenschutz $M$. Teenage marriage, and the socioeconomic status of hmong women. Int Migr. 2014;52(3):144-159.

http://doi.org/10.1111/j.1468-2435.2010.00674.x

23. Sandhu NK and Geethalakshmi RG. Determinants and impact of early marriage on mother and her newborn in an urban area of Davangere: A cross-sectional study. Int J Community Med Public Health. 2017;4(4):1278. http://doi.org/10.18203/2394-6040.ijcmph20171362

24. Montazeri S, Gharacheh M, Mohammadi N, Rad JA and Ardabili HE. Determinants of early marriage from married girls' perspectives in Iranian setting: A qualitative study. J Environ Public Health. 2016;2016:8615929. http://doi.org/10.1155/2016/8615929

25. Kerckhoff $A C$ and Parrow AA. The effect of early marriage on the educational attainment of young men. J Marriage Fam. 1979;41(1):97-107. http://doi.org/10.2307/351735

26. Biswas CS and Mukhopadhyay I. Marital status and women empowerment in India. Soc Int J. 2018;2(1):29-37. http://doi.org/10.15406/sij.2018.02.00030

27. Raj A, Saggurti N, Balaiah D and Silverman JG. Prevalence of child marriage and its effect on fertility and fertility-control outcomes of young women in India: A cross-sectional, observational study. Lancet. 2009;373(9678):1883-1889. http://doi.org/10.1016/S0140-6736(09)60246-4

28. Guntoory I, Tamaraba NR, Nambaru LR and Kalavakuri AS. Prevalence and sociodemographic correlates of vaginal discharge among married women of reproductive age group at a teaching hospital. Int J Reprod Contracept Obstet Gynecol. 2017;6(11):4840. http://doi.org/10.18203/2320-1770.ijrcog20174691

29. Yasmin S, Zaman NA and Zafreen F. Socio-demographic characteristics of women having vaginal discharge attending a military hospital. J Armed Forces Med Coll Bangladesh. 2020;14(2):183-185.

http://doi.org/10.3329/jafmc.v14i2.45905

30. Bhilwar M, Lal P, Sharma N, Bhalla P and Kumar A. Prevalence of reproductive tract infections and their determinants in married women residing in an urban slum of North-East Delhi, India. J Nat Sci Biol Med. 2015;6(Suppl 1):S29-S34. http://doi.org/10.4103/0976-9668.166059

31. Rahman $M$ and Kabir $M$. Knowledge of Adolescents on contraception and dynamics of its use. Health Popul Perspect Issues. 2005;28:164-177.

32. Yadav K, Agarwal M, Shukla M, Singh JV and Singh VK. Unmet need for family planning services among young married women (15-24 years) living in urban slums of India. BMC Womens Health. 2020;20(1):1-17. http://doi.org/10.1186/s12905-020-01010-9

33. Gupta S, Dave V, Sochaliya K and Yadav S. A study on sociodemographic and obstetric profile of MTP seekers at Guru. 


\section{2;3(1):50-54.}

34. Sathikumar M, Xavier AP, Austoria AJ, George JS, Das JS and Pillai G. A study on socio demographic profile and obstetric profile among MTP seekers from a tertiary care hospital in South India. J Med Sci Clin Res. 2017;5(12):132.

http://doi.org/10.18535/jmscr/v5i12.132

35. Barman B, Roy A, Zaveri A, Saha J and Chouhan P. Determining factors of institutional delivery in India: A study from national family health survey-4 (2015-16). Clin Epidemiol Glob Health. 2020;8(4):1335-1340.

http://doi.org/10.1016/j.cegh.2020.05.007

36. Godha D, Gage AJ, Hotchkiss DR and Cappa C. Predicting maternal health care use by age at marriage in multiple countries. J Adolesc Health. 2016;58(5):504-511.

http://doi.org/10.1016/j.jadohealth.2016.01.001

37. Uddin J, Pulok MH, Johnson RB, Rana J and Baker E. Association between child marriage and institutional delivery care services use in Bangladesh: Intersections between education and place of residence. Public Health. 2019;171:6-14. http://doi.org/10.1016/j.puhe.2019.03.014

38. Nasrullah M, Muazzam S, Bhutta ZA and Raj A. Girl child marriage and its effect on fertility in Pakistan: Findings from Pakistan demographic and health survey, 2006-2007. Matern Child Health J. 2014;18(3):534-543.

http://doi.org/10.1007/s10995-013-1269-y

\section{Authors Contribution:}

CC- Concept and design of the study, data collection, reviewed the literature; MNAK- statistical analysis and interpretation, preparation of manuscript; SA- preparation of manuscript, revision of the manuscript

\section{Work attributed to:}

JNU-IMRC, Jaipur, Rajasthan, India

Orcid ID:

Dr. Chintu Chaudhary - (1) https://orcid.org/0000-0003-4196-8651

Dr. Mohd. Najmul Aqib Khan - (1) https://orcid.org/0000-0001-6575-5023

Dr. Sameena Ahmad - (1) https://orcid.org/0000-0003-3279-1567

Source of Support: Nil, Conflict of Interest: None declared. 